This is an author-produced PDF of an article accepted for publication in Oxford Bibliographies Online: Music. The definitive publisher-authenticated version is available online at: DOI:

10.1093/obo/9780199757824-0105. Copyright Oxford Bibliographies Online. Complete citation information of that definitive version is: Grant, C. (2013). Music sustainability. In Oxford Bibliographies in Music. Ed. B. Gufstafson. New York: Oxford University Press. doi: 10.1093/obo/97801997578240105

Oxford Bibliographies Online: Music

Entry ID: 9780199757824-0105

Version Date: uploaddate

Citation style: Humanities

\title{
MUSIC SUSTAINABILITY
}

Catherine Grant

Queensland Conservatorium Research Centre, Griffith University

Introduction

General Overviews

Policy Instruments

Critiques

Copyright, IP, and Legal Issues

Musical Change

Music Revivals

Cultural and Musical Diversity

Globalization

Area Studies

Interdisciplinary Perspectives

\section{INTRODUCTION}

The sustainability of music is an emerging - or rather, re-emerging - theme in ethnomusicological research. Early studies in that discipline centered on documenting musical traditions feared doomed to extinction, an approach scholars now refer to as salvage ethnomusicology. Spurred by UNESCO's 2003 Convention on the Safeguarding of the Intangible Cultural Heritage and other national and international calls-to-arms, researchers and activists are increasingly re-engaging with the complex challenges of maintaining and revitalizing threatened music genres, particularly those of indigenous and minority peoples. Current approaches are more pragmatic than earlier ones. They typically acknowledge the natural emergence, change and decay of musical traditions as well as the many local and global processes that act upon all music genres, from technological developments and environmental shifts to rural-to-urban migration and economic and political pressures. Defining music sustainability as the ability of a music genre to endure, without implications of either a static tradition or a preservationist bearing, this article maps out a selection of scholarly publications, policy instruments, projects and initiatives, reports and online resources that relate to this topic.

\section{GENERAL OVERVIEWS}

Though much ethnomusicological research deals with issues closely related to the sustainability of musical cultures and the specific traditions that comprise them, including continuity and change (see ${ }^{*}$ Musical Change*), revival movements (see *Musical Revivals*), and the intersections between music, the local, and the global (see *Globalization*), relatively few sources deal in general terms directly with the topic of music sustainability. Titon 2009 offers perhaps the best general overview of the issues, presenting a variety of scholarly viewpoints in a themed edition of the journal World of Music. A concise introduction to the need for efforts to support sustainability is found in Schippers 
2010, an article which, like Titon's volume, presents a range of academic perspectives on supporting sustainability. In Fenn and Titon 2003, Titon presents his beliefs regarding the place of applied ethnomusicological work in solving "practical problems in the world outside the academy" (130), including initiatives (such as archival repatriation projects) that potentially impact on the viability of music genres. In the spirit of applied ethnomusicology, Lomax 1977 represents an early call for action against the adverse effects of globalization on cultural diversity. Two further general texts relating to music endangerment and preservation point to the interdisciplinary nature of music sustainability research (see *Interdisciplinary Perspectives*): Stubington 1987 employs an ecological framework to distinguish between preserving musical traditions and maintaining or revitalizing them in living form; and Marett 2009 refers to the field of language maintenance to argue for the need for urgent intervention in the endangerment and loss of music genres.

Fenn, John and Jeff Todd Titon. "A Conversation with Jeff Todd Titon." Folklore Forum 34.1/2 (2003): 119-131.

An email interview with Jeff Todd Titon centering on Titon's long-term involvement with applied ethnomusicology. The piece explores Titon's perspectives on the scope, methods, future directions, and ethical considerations inherent in applied work, including appropriate ethnomusicological approaches to change in music cultures.

Lomax, Alan. "An Appeal for Cultural Equity." Journal of Communication 27.2 (1977): 125-138. Warning of the threat of mass "cultural grey-out" resulting from globalization, Lomax argues vehemently for a global policy of cultural equity in order to counter a rapid loss of diversity and distinctiveness of cultural expressions across the world.

Marett, Allan. "Vanishing Songs: How Musical Extinctions Threaten the Planet: The Laurence Picken Memorial Lecture 2009." Ethnomusicology Forum 19.2 (2010): 249-262.

Drawing variously on research from the field of language endangerment, from that of British musicologist Picken, and from the author's own experience as a performer in an Australian Aboriginal ceremonial tradition, Marett argues that the repercussions of "vanished" music genres extends far beyond the communities in which the losses occur.

Schippers, Huib. "Three Journeys, Five Recollections, Seven Voices: Operationalising Sustainability in Music." In Applied Ethnomusicology: Historical and Contemporary Approaches. Edited by Klisala Harrison, Elizabeth Mackinlay and Svanibor Pettan, 50-60. Newcastle upon Tyne: Cambridge Scholars, 2010.

Taking the Vietnamese traditional sung genre ca trù as its key focus within an applied ethnomusicological framework, and supported extensively by perspectives on music sustainability from other scholars, this chapter positions Schippers' personal experiences as a music researcher against the need for efforts that help communities to keep their musical cultures strong.

Stubington, Jill. "Preservation and Conservation of Australian Traditional Musics: An Environmental Analogy." Musicology Australia 10.2 (1987): 2-15.

Drawing on discourse from environmental sustainability, Stubington distinguishes between preservation (essentially documentation) and conservation (maintenance or revitalization) of music genres, with examples from the Australian context.

Titon, Jeff Todd, ed. World of Music 51.1 (2009). Bamberg: Department of Ethnomusicology, OttoFriedrich-University.

This special issue of the journal World of Music, "Music and Sustainability", explores issues relating to cultural and musical viability. The relevance of ecological models is a salient theme, including the suggestion that theory and practice relating to music sustainability 
should take into account the interdependence of the wider "ecosystem" in which music is situated.

\section{POLICY INSTRUMENTS}

Many policy instruments form tools of reference through which nation-states can take steps to protect and promote intangible cultural heritage, including music. The transnational policies of the Council of Europe 2000 and the European Commission 2007 grew from the necessity to promote cultural diversity across member states. Almost certainly the most influential of policy instruments at the international level are the conventions, declarations, and treaties developed over the past decades by the United Nations Educational, Scientific and Cultural Organization (UNESCO), which form a foundation on which governments, policy-makers, non-government organizations and other stakeholders may develop practical approaches to strengthen cultural (including musical) sustainability. The declaration of the United Nations High Commission for Human Rights on the rights of indigenous peoples (UNHCHR 2007), as well as the instruments of UNESCO 1989 and UNESCO 2003 on safeguarding traditional cultural expressions and of UNESCO 2001 and UNESCO 2005 on protecting and promoting cultural diversity, have had considerable international influence, and in some cases benefits have demonstrably flowed down to the community level. Nevertheless, these instruments and their various associated "safeguarding" projects have attracted criticism for their sometimes unexpected or even adverse consequences, such as the 'freezing' of a tradition, or heightened disagreement among culture-bearers about the appropriate future trajectory of a genre. Some of the literature tabling these concerns is outlined in the subsection ${ }^{*}$ Critiques* $^{*}$.

Council of Europe. *Declaration on Cultural Diversity[http://www.ebu.ch/CMSimages/en/leg_t_gats_coe_decl_cultural_diversity_071200_tcm64311.pdf] 2000 (accessed 10 June 2012).

The outcome of a meeting of the Committee of Ministers of the Council of Europe, this instrument underscores the necessity of supporting sustainable cultural diversity in an increasingly globalized world. It includes recommendations to member states for appropriate audiovisual (technology-related) policies that promote and respect cultural diversity.

European Commission. European Agenda for Culture in a Globalising

World[http://ec.europa.eu/culture/our-policy-development/european-agenda-for-culture_en.htm] ${ }^{*}$, 2007 (accessed 10 June 2012).

A strategy for cultural cooperation that attempts to take into account the realities of globalization. The Agenda aimed to stimulate intercultural dialogue and cultural diversity in the European Union, also making recommendations on creativity as a driver of economic stimulus and an important element in promoting international relations.

UNESCO. *Recommendation on the Safeguarding of Traditional Culture and Folklore [http://portal.unesco.org/en/ev.phpURL_ID=13141\&URL_DO=DO_PRINTPAGE\&URL_SECTION=201.html] ${ }^{*}, 1989$ (accessed 27 January 2012).

Underscores the value of traditional cultural heritage in social and cultural identity, recognizes the "extreme fragility of the traditional forms of folklore, particularly those aspects relating to oral tradition and the risk that they might be lost" (para. 1), and encourages governments to act swiftly to safeguard these traditions.

UNESCO. *Universal Declaration on Cultural Diversity[http://portal.unesco.org/en/ev.phpURL_ID=13179\&URL_DO=DO_TOPIC\&URL_SECTION=201.html], 2001 (accessed 27 January 2012).

States that globalization not only creates challenges for cultural diversity but also presents opportunities for intercultural dialogue and exchange, declares the social, economic, and 
creative value and importance of cultural diversity and the cultural industries, and reiterates the human right to participate in and express one's own culture.

UNESCO. *Convention for the Safeguarding of Intangible Cultural

Heritage[http://portal.unesco.org/en/ev.php-

URL_ID=17716\&URL_DO=DO_TOPIC\&URL_SECTION=201.html], 2003 (accessed 27 January 2012).

Articulates the urgent need for measures to ensure the viability of intangible cultural heritage worldwide. Such measures, according to the convention, include identifying cultural expressions in need of support, as well as activities relating to documentation, research, protection, promotion, transmission and revitalization.

UNESCO. ${ }^{*}$ Convention on the Protection and Promotion of the Diversity of Cultural

Expressions[http://www.unesco.org/new/en/culture/themes/cultural-diversity/diversity-of-culturalexpressions/the-convention/convention-text/], 2005 (accessed 27 January 2012).

Like the 2001 Declaration, affirms the importance of cultural diversity in human rights, as well as for individuals and societies. One of the tenets of this convention is that the protection and promotion of a diversity of cultures, including those of indigenous and minority peoples, is essential for sustainable development.

United Nations High Commission for Human Rights. *Declaration on the Rights of Indigenous Peoples[http://www2.ohchr.org/english/issues/indigenous/declaration.htm] ${ }^{*}, 2007$ (accessed 27 January 2012).

Establishes a framework for human and cultural rights and identity of indigenous peoples, individually and collectively. Asserts that indigenous peoples have the right to maintain, transmit and develop their traditional cultural expressions, including performing arts, and encourages States to ensure this right is protected.

\section{Critiques}

While "top-down" initiatives have the ability to raise the prestige of certain musical traditions and to celebrate and support musicians and music practices, they run the risk of being undermined by a complex set of issues including a lack of grassroots understanding, resources, control, and ownership that typically characterizes approaches developed and implemented at the community level. For this reason, such measures have sometimes had unexpected or even adverse consequences on the very traditions and communities they aim to protect. Loomis 1983 assesses the impact of cultural conservation policies and agencies in the United States, while Smith and Akagawa 2009 offers critical reflections on national and international policies and regulations that explicitly or implicitly aim to protect or promote cultural expressions and culture-bearers, including (but not limited to) the various instruments of UNESCO described in *Policy Instruments*. A critical examination of the involvement of one music-specific non-government organization in the evaluation processes for nominations to UNESCO's Masterpieces of Humanity list is provided in Seeger 2009. Also with a focus on music, Titon 2009 includes an extensive assessment of some flaws of international initiatives and policies, including examples of equivocal consequences for the communities and cultural forms in question. A case study is provided in Wang 2003, which argues that the results of state intervention in Taiwanese nanguan have been, on the whole, decidedly adverse. Loomis, Ormond. Cultural Conservation: The Protection of Cultural Heritage in the United States: A study. Washington, DC: Library of Congress, 1983.

A summary of findings from The Conservation of Culture project coordinated by Loomis for the American Folklife Center. Although now outdated, this remains an insightful critique of the implementation and outcomes of cultural conservation policies, initiatives, and resource management efforts in the United States at local, state and federal level. 
Titon, Jeff Todd. "Music and Sustainability: An Ecological Viewpoint." World of Music 51.1 (2009): 119-137.

With regard to cultural policy approaches to music and sustainability, Titon makes the case for adopting four principles from the "new conservation ecology": those relating to diversity, limits to growth, connectedness, and stewardship. Includes a critical appraisal of the concept of "cultural heritage" as it is found (for example) in UNESCO's safeguarding schemes.

Seeger, Anthony. "Lessons Learned from the ICTM (NGO) Evaluation of Nominations for the UNESCO Masterpieces of the Oral and Intangible Heritage of Humanity, 2001-5." In Intangible Heritage. Edited by Laura-Jane Smith and Natsuko Akagawa, 112-128. London: Routledge, 2009. Critically evaluates the involvement from 2001-2005 of the non-government International Council of Traditional Music in UNESCO's Masterpieces initiative, including the impact of the evaluation processes and procedures on the outcomes of the scheme.

Smith, Laura-Jane, and Natsuko Akagawa, eds. Intangible Heritage. London: Routledge, 2009. Theorizes, deconstructs, and critiques national and international policy approaches to intangible cultural heritage and its safeguarding, from a range of scholarly perspectives. While the volume is not music-specific, many of its themes are directly relevant to key issues and challenges in music sustainability.

Wang, Ying-Fen. "Amateur Music Clubs and State Intervention: The Case of Nanguan Music in Postwar Taiwan." Journal of Chinese Ritual, Theatre and Folklore 141 (2003): 95-167.

Documents the equivocal effects of state policy intervention in the 1980s and 1990s on Taiwanese nanguan. Wang argues that aside from the general failure of intervention to protect and transmit nanguan, intervention resulted in the compromised integrity of nanguan musicians and the "commodification, vulgarization, and theatricalization" (152) of the music itself.

\section{COPYRIGHT, IP, AND LEGAL ISSUES}

Copyright, Intellectual Property, and legal issues can play a decisive role in the dissemination, distribution, and even the general trajectory of musical traditions. Letts 2005, for example, examines the impact of free trade agreements on the music cultures of five countries. Blaukopf 1990 enumerates concrete ways in which policy and legal measures in areas like media, education, and copyright might be used to benefit the cause of music sustainability, and Kono 2009 examines areas of intersection between cultural heritage and intellectual property law in particular. World Intellectual Property Organization's ${ }^{* *}$ Creative Heritage Project ${ }^{* *}$ develops and maintains codes of practice, guidelines, protocols, and other resources for dealing with intellectual property issues that arise when documenting, digitizing, archiving, and disseminating intangible heritage.

Blaukopf, Kurt. "Legal Policies for the Safeguarding of Traditional Music: Are They Utopian?" World of Music 32.1 (1990): 125-133.

Blaukopf gives a number of examples of possible legal or contractual policy measures that may help protect "small" music genres in the face of "radical change" (especially due to electronic media) - for example, by raising funds for documentation, research, transmission or revitalization initiatives.

Kono, Toshiyuki, ed. Intangible Cultural Heritage and Intellectual Property: Communities, Cultural Diversity and Sustainable Development. Antwerp: Intersentia, 2009.

This edited volume explores key issues and challenges in the nexus between intangible cultural heritage and intellectual property law. Topics include the practice of compiling "inventories" of cultural heritage, ethical issues relating to community ownership, and the benefits and challenges of regulatory measures to protect intangible heritage. 
Letts, Richard. "*The Effects of Globalization on Music in Five Contrasting Countries: Australia, Germany, Nigeria, the Philippines and Uruguay[http://www.mca.org.au/research/researchreports/research-reports/638-the-effects-of-globalisation-on-music-in-five-contrasting-countriesaustralia-germany-nigeria-the-philippines-and-uruguay]." Paris, Sydney: International Music Council, Music Council of Australia, 2003 (accessed 27 January 2012).

Taking as its case studies the music cultures of Australia, Germany, Nigeria, the Philippines and Uruguay, this report provides a sharp analysis of the actual and potential effects of free trade agreements on the local cultures and musics of those nation-states.

World Intellectual Property Organization. *Creative Heritage

Project[http://www.wipo.int/tk/en/culturalheritage/], n.d.

A resource-base for developing best practices to manage intellectual property rights relating to creative heritage, including music. The project reviews existing practices, protocols, and policies, and explores topics ranging from the use of digital technologies in documentation projects, to intellectual property management in archives, to issues of intellectual property in relation to arts festivals.

\section{PROJECTS AND INITIATIVES}

Over the past decade or two, projects and initiatives relating to music sustainability have increasingly been designed on the premise that they should grow out of the concerns and needs of communities themselves, rather than overarching policy, systemic, or governmental demands, or the interests of academics or others in positions of power. Within ethnomusicological studies, this approach is now underpinned by the philosophical framework of the growing sub-discipline applied ethnomusicology (in the US, engaged ethnomusicology). An example of this ethos in practice is the five-year ongoing ${ }^{* *}$ Sustainable Futures for Music Cultures ${ }^{* *}$ research project; its website describes how the outcomes will be used to help communities striving to maintain their musical practices. Many of the cultural heritage safeguarding projects described in UNESCO 2010 also adopt this principle, albeit not necessarily within the framework of applied ethnomusicology. Country-specific projects endeavoring to directly benefit the communities concerned include Afghanistan National Institute of Music 2009, a transmission initiative aimed at revitalizing the traditional music of that country; and the project described in Corn 2007, with its goal to systematically document Australian Indigenous music. Underscoring the ongoing and important role of documentation, archiving and repatriation initiatives in safeguarding music are institutes such as the seminal ${ }^{* *}$ Archives and Research Centre for Ethnomusicology, New Delhi** and the 20-plus archives falling under the umbrella of the ${ }^{* *}$ Digital Endangered Languages and Musics Archives Network** (DELEMAN). Networks like DELEMAN play an important role in gathering and disseminating information about issues relating to music sustainability. Another prominent example is International Network for Cultural Diversity 2002-2003, founded with the aim of promoting cultural diversity in the face of an increasingly globalized world. The range of possible approaches to supporting cultural heritage combined with the complexity of the issues has resulted in the need for guidance for governments, non-government organizations, cultural researchers, archives, and other stakeholders. One example of such direction is UNESCO 2002, which sets out guidelines for establishing national "Living Human Treasures" systems (another is the World Intellectual Property Organization's ${ }^{* *}$ Creative Heritage Project ${ }^{* *}$ listed under ${ }^{*}$ Copyright, IP, and Legal Issues*).

*Archives and Research Centre for Ethnomusicology, New

Delhi*[http://www.aiislanguageprograms.org/ethnomusicology.php $]^{*}$, n.d.

Established in 1982, ARCE is the most extensive repository of audio and video documentation of the performing arts of India, and has served a model for other third-world archives. It also undertakes research and archive training projects, and is concerned with the sustainable preservation of its recordings. 
*Afghanistan National Institute of Music[http://www.afghanistannationalinstituteofmusic.org/]*, 2009. The website of a dedicated music institute established on the basis of a recommendation of the project Revival of Afghan Music. The institute aims not only to help revitalize traditional Afghan musical instruments and forms, but also lives destroyed by the years of warfare and repression.

Corn, Aaron. *National Recording Project for Indigenous Music in

Australia[http://www.aboriginalartists.com.au/NRP.htm] ${ }^{*}, 2007$.

This project aims "to systematically record and document the unique and endangered performance traditions of Indigenous Australia" ("Vision" section, para. 1). An overarching goal is to stimulate community interest and practice of performance traditions through documentation and archiving, thereby contributing to community efforts to ensure cultural sustainability.

*Digital Endangered Languages and Musics Archives Network[http://www.delaman.org/], n.d. A network of national and international archives for endangered music genres (and languages), including the Pacific and Regional Archive for Digital Sources in Endangered Cultures (PARADISEC) and the Endangered Languages Archive (ELAR) of the Hans Rausing Endangered Languages Program at the University of London.

*International Network for Cultural Diversity[http://www.incd.net/incden.html]", 2002-2003.

The website of a non-government organization that works with artists, cultural institutions, researchers, and industry workers to promote cultural diversity and to counter the adverse effects of globalization on cultural heritage.

Queensland Conservatorium Research Centre. *Sustainable Futures for Music

Cultures[http://musecology.griffith.edu.au/]", n.d.

The website of a five-year Australian-led research project investigating the dynamics of music sustainability, as well as ways to help communities maintain their musical practices. The site includes case studies, as well as details about the approach and projected outcomes of the project.

UNESCO. *Kit of the Convention for the Safeguarding of the Intangible Cultural Heritage[http://www.unesco.org/culture/ich/index.php?lg=en\&pg=00018\#7]", 2010 (accessed 27 January 2012).

From the section "Fact sheets on Intangible Cultural Heritage" can be downloaded a set of introductory information sheets on selected UNESCO safeguarding projects, including the music-related Revival of intergenerational transmission of Georgian traditional polyphony, The value of old recordings today: the case of Papua New Guinea, and Documentation of musical heritage in Hungary.

UNESCO Section of Intangible Heritage / Korean National Commission for UNESCO (2002). *Guidelines for the Establishment of National "Living Human

Treasures[http://unesdoc.unesco.org/images/0012/001295/129520eo.pdf]" Systems (updated version), 2002 (accessed 27 January 2012).

Now operating in several countries (most saliently, Japan and Korea), Living Human Treasures schemes identify, support, and celebrate individuals who hold outstanding skills in a form of cultural heritage, and persuade them to develop their practice and pass on their skills. These official (updated) guidelines set out the aims and methods of the system. 


\section{MUSICAL CHANGE}

Expedited by the rise of mass media, information technology, international travel and tourism, and shifting populations, cultural change has sometimes led to a renewal or revitalization of "small" music genres. On the other hand, cross-cultural contact has been accused by some scholars of effecting local or even global musical homogenization. Theories relating to musical transculturation, as well as the synergetic oppositions between tradition and innovation, purism and syncretism, and continuity and change, have featured prominently in ethnomusicological research over the past several decades. They inform our understanding of the dynamics of musical vitality and sustainability in various ways. Malm 1993, for example, elucidates the impact on music cultures of mass media and the music industry (see also *Globalization*), and Kartomi and Blum 1994 and Nettl 2005 identify and illustrate a spectrum of possible processes and outcomes of contact between music cultures. Case studies of musical change in specific communities can be found in the section on *Musical Change*.

Kartomi, Margaret and Stephen Blum, eds. Music-cultures in Contact: Convergences and Collisions. Sydney: Currency Press, 1994.

This edited volume examines how and why contact engenders change in music cultures. With case studies from around the world, it describes the range of positive and negative effects contact may have on the nature, vitality, and viability of music genres.

Malm, Krister. "Music on the Move: Traditions and Mass Media. Ethnomusicology 37.3 (1993): 339352.

Includes a typology of the processes and effects of cross-cultural contact on "traditional" genres, taking into account the mechanisms of the music industry. Malm identifies and defines four main possible effects of contact on music genres, which may impact the local genres in various ways, both advantageously and detrimentally.

Nettl, Bruno. The Study of Ethnomusicology: Thirty-one Issues and Concepts. 2nd ed. Urbana: University of Illinois Press, 2005.

The second edition of Nettl's 1983 classic introduction to ethnomusicology. While the issue of musical change (and sustainability at large) arises on occasion throughout the book, Chapter 20, "The continuity of change: On people changing their music" (pp. 272-290) offers a concise overview of historical and contemporary scholarly thinking on the topic.

\section{MUSICAL REVIVALS}

Livingston 1999 defines music revivals as social movements, often driven by an explicit cultural or political agenda, that strive to renew a disappearing musical tradition or practice (66). Case studies of revivals and their attendant constructs hold significant potential to inform theory on music sustainability, not least by providing insight into the dynamics of the continuity, change, and viability of music genres in the contemporary global environment. Examples provided here are Frigyesi 1996 on the folk music revival in Hungary, Filene 2000 on folk revivals in the United States, and Jovanović 2005 and 2010 on the resurgence of folk songs in Serbia. However, folk revival movements reveal considerable differences between them, underscoring underscores the difficulty of constructing a general theory of revivals. The seminal theoretical research of Rosenberg 1993, Baumann 1996, and Livingston 1999 continues to serve as a foundation for understanding the processes and products of musical revivals. Paradoxically, alongside concepts and constructs of authenticity and tradition, those of musical transformation and innovation are often at the core of these theories; for this reason, many of the sources in this section have areas of overlap with those listed under *Musical Change*.

Baumann, Max Peter, ed. World of Music 38.3 (1996). Berlin: International Institute for Traditional Music. 
This special issue on "Folk Music Revival in Europe" presents five articles appraising the processes and outcomes of folk music revivals in the European context. Articles by Ronström (5-20) and Baumann (71-86) in particular reassess revival concepts and theory.

Filene, Benjamin. Romancing the Folk: Public Memory and American Roots Music. Chapel Hill, North Carolina: UNC Press Books, 2000.

Explores a number of key issues relating to revivals in the context of American folk music, including commercialization and corporatization, perceptions of authenticity, and the role of the mass media in sustainability. Also describes the efforts of key figures in the preservation and promotion of American roots music.

Frigyesi, Judit. "The Aesthetic of the Hungarian Revival Movement." In Returning Culture: Musical Changes in Central and Eastern Europe. Edited by Mark Slobin, 54-75. Durham: Duke University Press, 1996.

A case study of the role of music in the politics of culture, this chapter explores the revival, modernization, and social recontextualization through to the mid-1990s of Hungarian folk dance music, including its use as a means of promoting a national identity.

Jovanović, Jelena. "The Power of Recently Revitalized Serbian Rural Folk Music in Urban Settings." In Music, Power, Politics. Edited by Annie J. Randall, 133-142. New York: Routledge, 2005.

Jovanović details from a historical, socioeconomic and political perspective the revitalization of rural folk song genres in Serbian towns in the 1990s. The article surveys the multifaceted effects on musicians and audiences of reclaiming this ethnic heritage.

Jovanović, Jelena. "Questioning the Possibility of Revitalising Traditional Rural Songs in Topola, Serbia." In Applied Ethnomusicology: Historical and Contemporary Approaches. Edited by Klisala Harrison, Elizabeth Mackinlay and Svanibor Pettan, 161-181. Newcastle upon Tyne: Cambridge Scholars, 2010.

A case study assessing the potential to revive, through an activist approach, a set of highly endangered peasant songs in rural Serbia. The article documents the author's efforts as director of a village youth choir to revitalize these songs for performances and competitions, yet remain sensitive to their historical and social significance.

Livingston, Tamara E. "Music Revivals: Towards a General Theory." Ethnomusicology 43.1 (1999): 66-85.

Livingston identifies six basic ingredients that together form the musical revival "recipe", in a theoretical model that attempts to allow for the uniqueness of each situation of music revival.

Rosenberg, Neil V., ed. Transforming Tradition: Folk Music Revivals Examined. Urbana: University of Illinois Press, 1993.

A collection of fifteen contributions around many of the core themes of music revival theory and practice, including invented traditions, political impetuses, and constructions of authenticity. Examples are mainly from North America.

\section{CULTURAL AND MUSICAL DIVERSITY}

The issue of cultural and musical diversity is intricately connected with the sustainability of music genres: the loss of music genres diminishes the cultural diversity of the planet. By their very nature, efforts to foster cultural diversity - such as those described in Letts 2005, a detailed appraisal of ways to protect and promote musical diversity in particular - often entail preventing the endangerment and loss of cultural expressions. The remaining sources in this section are characterized by a focus on the interrelationship between cultural diversity and another field of enquiry. Berger and Huntington 2002 offers perspectives on the nexus between cultural diversity and globalization (see also 
*Globalization*); Harmon 2002 outlines the very real links between efforts to protect biological and cultural diversity; and Schippers 2010 and Campbell et al. 2005 both explore the intersection of cultural diversity with music education (see also *Interdisciplinary Perspectives*).

Berger, Peter L., and Samuel P. Huntington, eds. Many Globalizations: Cultural Diversity in the Contemporary World. New York: Oxford University Press, 2002.

Exploring the dynamics of globalization within and between cultures, this edited volume brings together case studies from across five continents that highlight the positive, adverse, and sometimes surprising effects of globalization on cultural diversity.

Campbell, Patricia S., John Drummond, Peter Dunbar-Hall, Keith Howard, Huib Schippers, and Trevor Wiggins, eds. Cultural Diversity in Music Education: Directions and Challenges for the 21st Century. Bowen Hills: Australian Academic Press, 2005.

Offering both scholarly and practice-based perspectives, this edited volume chronicles current developments in a field that has recently gained ground in the theory and practice of music education. It outlines some of the advantages, opportunities, risks and challenges of incorporating cultural diversity in music education.

Letts, Richard. "*The Protection and Promotion of Musical Diversity[http://www.imc-

cim.org/images/stories/programmes/imc_diversity_report.pdf]." Paris: International Music Council, 2005 (accessed 27 January 2012).

Commissioned by UNESCO from the International Music Council, this report appraises the risk of cultural homogenization and argues for a need to actively protect and promote diverse musical expressions. Consultants' reports (as Appendices) offer invaluable insights into issues surrounding musical diversity in specific regions of the world.

Schippers, Huib. Facing the Music. New York: Oxford University Press, 2010.

Schippers investigates practices and ideas that have developed from a growing awareness of the need for cultural diversity in music education. He assesses the complexities and potential of learning and teaching music "out of context", and explicitly relates musical diversity in education to issues of music sustainability.

\section{GLOBALIZATION}

One of the most obvious advantages of globalization in relation to music is the vastly increased access to "small" music genres, at least among those with access to modern technology. Yet globalization can bring with it commoditization, exploitation, and cultural homogenization that in some cases may unfavorably affect the vitality of music genres and entire music cultures. Mundy 2001 explores this issue at the heart of discourse on music sustainability: whether an increasingly globalized world is bringing about "a musical life of wonderful flexibility and intellectual breadth" (14) or is expediting the atrophy of genres that do not find a ready place in the global environment. Mass media technologies have massively intensified the processes of globalization, and therefore often figure prominently in theories about the nexus between globalization, culture, and sustainability. Taylor 1997, Stokes 2004, and Slobin 2003 identify a raft of problems including appropriation, commodification, exploitation, and piracy, but also the potential for mass dissemination and access to music that may potentially profit musicians, communities, and the viability of "small" music genres. Letts 2003 examines the potential and actual role of governmental policies in sustaining diverse and vibrant musical expressions against the forces of a globalizing world, and examples of the effects of globalization on particular music genres and geographical regions are provided in Hayward and Kuwahara 2008 (shima uta, Amami islands, Japan), Kaeppler 2010 (Hawai'ian hula), and Loza 2003 (Latin America). 
Hayward, Phil, and Sueo Kuwahara. "Transience and Durability: Music Industry Initiatives, Shima Uta and the Maintenance of Amami Culture." Perfect Beat: The Pacific Journal of Research into Contemporary Music and Popular Culture 8.4 (2008): 44-63.

Analyses the contemporary situation of the traditional song genre shima uta from the Amami islands in southern Japan, and the role of the music industry in promoting it. Hayward and Kuwahara relate recent scholarly debates about the nature of "world music" to issues of tradition and cultural maintenance.

Kaeppler, Adrienne. "The Beholder's Share: Viewing Music and Dance in a Globalized World." Ethnomusicology 54.2 (2010): 185-201.

Examines the ways in and through which Hawai'ian hula has come to be recognized as an "international performative language". Kaeppler positions hula in relation to discourses on globalization, focusing on the role of audiences in "decoding" performances.

Letts, Richard. "* The Effects of Globalization on Music in Five Contrasting Countries: Australia, Germany, Nigeria, the Philippines and Uruguay[http://www.mca.org.au/research/researchreports/research-reports/638-the-effects-of-globalisation-on-music-in-five-contrasting-countriesaustralia-germany-nigeria-the-philippines-and-uruguay] ." Paris, Sydney: International Music Council, Music Council of Australia, 2003 (accessed 27 January 2012).

Commissioned by the International Music Council and executed by the Music Council of Australia, this report examines the ongoing consequences of globalization for the local musics of Australia, Germany, Nigeria, the Philippines and Uruguay.

Loza, Stephen J., ed., Musical Cultures of Latin America: Global Effects, Past and Present. Los Angeles: Department of Ethnomusicology and Systematic Musicology, University of California, 2003. A collection of thirty-one papers analyzing global influences on the music of Latin America. A key topic is the effect of intercultural and intercontinental movements on local traditional and popular genres. Many of the concepts relating to globalization and its processes hold relevance well beyond Latin America.

Mundy, Simon. Music and Globalisation: A Guide to the Issues. Paris: International Music Council, 2001.

A succinct and readable guide to the key concepts and arguments around music and globalization. Mundy's explicit aims are to reveal how globalization - as a political as well as economic process - holds both positive and negative outcomes for music, and to suggest strategies to mitigate the latter.

Slobin, Mark. Subcultural Sounds: Micromusics of the West. Middletown, CT: Wesleyan University Press, 1993.

A critical study of how subcultural musics, or what Slobin calls "small musics in big systems," often represent a search for cultural identity within multiethnic societies in an increasingly globalized world. Subcultural Sounds explores the dynamics of this process in Europe and America.

Stokes, Martin. "Music and the Global Order." Annual Review of Anthropology 33 (2004): 47-72. An extensive and somewhat technical review of anthropological and ethnomusicological sources from the late 1980s to 2004 , in which Stokes evaluates diverse and shifting perspectives on global music circulation and the ways in which music is conceptually positioned in relation to globalization.

Taylor, Timothy. Global Pop: World Music, World Markets. New York: Routledge, 1997. 
Drawing on both scholarly and non-scholarly sources, Taylor examines the rise of world music, its performers and consumers, the discourses employed in and around it, and some of the genres and styles that have come to represent it. An accessible introduction to ways of thinking about the global flow of music and cultures.

\section{AREA STUDIES}

Case studies of endangered music genres and cultures, as well as studies of musical change and revivals, give considerable insight into the processes of music sustainability. Of the numerous ethnomusicological and anthropological case studies of musical change within communities, a selection is provided here by way of example. Diettrich, Moulin and Webb 2011 provides an introduction to the impact of cultural exchange and globalism on music in the Pacific Islands; Hesselink 2004 examines the tension between the "old" and the "new" in describing the revitalization of a Korean percussion tradition; Moyle 2007 describes the cultural consequences of the fastchanging environmental and socio-political situation on the Polynesian atoll Takū; and Kramer 2007 assesses the contemporary relevance and viability of Western classical music. Through an in-depth study of Korean music, Howard 2006 provides keen insight into key challenges of preserving, protecting, and promoting the musical heritage of a nation-state. With regard to revivals and resurgences of interest in music genres, Ramnarine 2003 explores Finnish folk music, and Sheehy 2006, Mexican mariachi.

Diettrich, Brian, Jane Freeman Moulin, and Michael Hugh Webb. Music in Pacific Island Cultures: Experiencing Music, Expressing Culture. New York: Oxford University Press, 2011.

An undergraduate-level case study volume from the Global Music Series, with a key theme being the effects of cultural exchange and globalization on the diverse musical expressions of the Pacific Islands. Comes with accompanying CD, and an instructor's manual on the companion website.

Hesselink, Nathan. "Samul Nori as Traditional: Preservation and Innovation in a South Korean Contemporary Percussion Genre." Ethnomusicology 48.3 (2004): 405-439.

This article describes the regeneration of the Korean folk genre p'ungmul (formerly "a familiar, yet declining age-old rural practice"; 405), considers the political and social context in which the revitalization occurred, and examines the relationship between p'ungmul and the new tradition that arose from it, samul nori.

Howard, Keith. Preserving Korean Music: Intangible Cultural Properties as Icons of Identity. Aldershot, England; Burlington, VT: Ashgate, 2006.

This first of a two-volume set on Korean music explores a range of issues directly related to sustainability, including concepts of "tradition", the role of music in Korean national identity, and the processes and rationale of efforts - particularly those state-driven - to preserve and promote local and national traditions. Comes with accompanying CD.

Kramer, Lawrence. Why Classical Music Still Matters. Berkeley: University of California Press, 2007. Stimulated by predictions over the last decade or more of its demise, this book assesses the vitality and viability of Western art music. Kramer affirms the continued value of classical music, but also argues for the need for it to adapt in response to changing social and cultural environments.

Moyle, Richard. Songs from the Second Float: A Musical Ethnography of Takū Atoll, Papua New Guinea. Honolulu: University of Hawai'i Press, 2007.

This ethnography of the musical life of a Polynesian community draws on local voices to describe the impact of geographical isolation, a local ban on missionaries and churches, 
rising sea levels, and various other circumstances on their unique music practices. The future of the music of Takū is assessed.

Ramnarine, Tina K. IImater's Inspiration: Nationalism, Globalization, and the Changing Soundscapes of Finnish Folk Music. Chicago, IL: University of Chicago Press, 2003.

Exploring how Finnish "new folk" musicians think and talk about folk music practices, and examining the role of folk music in portraying national identity, Ramnarine raises key questions about the relationship between "new" and "old" in musical traditions, with implications for ways of thinking about issues of sustainability.

Sheehy, Daniel. Mariachi Music in America: Experiencing Music, Expressing Culture. New York: Oxford University Press, 2006.

A case study volume from the Global Music Series, in which Sheehy describes the phenomenon of the growing popularity over the last three decades of Mexican mariachi music in the United States. Amply illustrated and accompanied by a CD, this is an accessible appraisal of the "reinvention" of a genre.

\section{INTERDISCIPLINARY PERSPECTIVES}

Since music does not exist in isolation from people, society, culture, or the environment, music sustainability is by its nature an interdisciplinary topic of study. The sources listed in this section exemplify a wide variety of ways in which perspectives from outside of music research may be relevant for music sustainability. The controversial anthropological text by Turnbull 1972 gave rise to discussion in the fields of anthropology and ethnomusicology (and others) about the ethical responsibilities of engaging with a community facing significant external and internal pressures. Grant 2012 identifies and responds to four key ethical concerns surrounding sustaining endangered music genres, including the role of the researcher, by referring to discourse from language maintenance. Two further sources likewise bridge the fields of language and music: Grant 2010 identifies conceptual analogies between the viability of each; and Marett and Barwick 2003 argue that efforts to document endangered musical traditions are needed not only for their own sake, but for linguistic reasons too. Feld 1990 draws on approaches from anthropology, linguistics, ethnology and ethnomusicology to provide an account of one specific culture, including the imperilment of its sound world due to forest degradation. Finally, Maffi and Woodley 2010 present an anthology of projects that take an integrated approach to the sustainability of natural environments, languages, cultures, and biological diversity.

Feld, Stephen. Sound and Sentiment: Birds, Weeping, Poetics, and Song in Kaluli Expression. 2nd ed. Philadelphia: University of Pennsylvania Press, 1990.

Weaving together approaches from ethnology, anthropology, and linguistics, this landmark ethnography of the Kaluli people of Papua New Guinea demonstrates how sounds provide key insights into Kaluli society. It also points to the interconnectedness of the natural forest environment and Kaluli cultural expressions, including song.

Grant, Catherine. "The Links between Safeguarding Language and Safeguarding Musical Heritage." International Journal of Intangible Heritage 5 (2010): 44-59.

Identifies conceptual parallels between supporting the sustainability of music and of languages, and explores one of them in depth: the tensions, in both cases, between documenting versus revitalizing. The paper argues that the field of language maintenance holds significant potential to progress understanding of music sustainability.

Grant, Catherine. "Rethinking Safeguarding: Objections and Responses to Protecting and Promoting Endangered Musical Heritage." Ethnomusicology Forum 21.1 (2012): 31-51. 
Identifies and discusses four key ethical and pragmatic concerns relating to efforts to safeguard music genres, and argues that recourse to the field of language maintenance represents a pathway to responding adequately to those concerns.

Maffi, Luisa and Ellen Woodley, eds., Biocultural Diversity Conservation: A Global Sourcebook. London: Earthscan, 2010.

A compendium of 45 projects exemplifying current practice in the relatively new field of biocultural diversity, which explores the relationship between the sustainability of natural environments and human cultures.

Marett, Allan, and Linda Barwick. "Endangered Songs and Endangered Languages." In Maintaining the Links: Language, Identity and the Land, proceedings of Seventh FEL Conference, Broome, Western Australia, 22-24 September 2003. Edited by R. McKenna Brown and Joe Blythe, 144-151. Bath, UK: Foundation for Endangered Languages, 2003.

Taking a number of case studies from Australian Indigenous song genres, this paper argues for the urgency and importance of documenting song language. It also suggests that researcher-community collaborations to this end can revitalize a community's interest in, and practice of, song repertoires.

Turnbull, Colin M. The Mountain People. New York: Simon and Schuster, 1972.

Turnbull's involvement with the Ik people of Northern Uganda as described in this ethnography gave rise in the anthropological literature to extensive deliberations about the obligations that come with close researcher involvement with a community undergoing radical change - an important consideration for ethnomusicologists working on issues of music sustainability. 